\title{
CHARACTERISATION OF METAL RETENTION AGENTS AND STUDY OF THEIR APPLICATION IN LIQUID WASTES
}

N. XIROKOSTAS

A. KORKOLIS

L. DIAMANTOPOULOU

Th. ZARKATHOULA

\section{A. MOUTSATSOU*}

Selected from papers presented at the 7th Conference on Environmental Science and Technology,

3 - 6 September 2001, Ermoupolis, Syros island, Greece.
Laboratories of Inorganic and Analytical Chemistry, Department of Chemical Engineering, National Technical University of Athens, Heroon Polytechniou 9, Zografou Campus, 157-73, Athens, Greece

*to whom all correspondence should be addressed: fax: + (30) 2107723263,2107723188 e-mail: angst@central.ntua.gr

\section{ABSTRACT}

A procedure that should be implemented for the evaluation of materials suitability, in terms of their use as metal retention agents, is presented. It derives from a review of materials and waste treatment mechanisms, which has been studied and is also presented. Lignite fly ash, agricultural ashes, lime and sawdust were chosen for the experimental study of their metal uptake capacity, according to the proposed stages, during the treatment of an acidic liquid waste loaded with metals $(\mathrm{Cu}, \mathrm{Zn}, \mathrm{Fe}, \mathrm{Ni}, \mathrm{Cd}$, $\mathrm{Cr}$ ). Fly ash, agricultural ashes and lime exhibited increased metal retention percentages through adsorption and precipitation, as it was expected due to their structure, while sawdust acted as sorbent.

KEYWORDS: Precipitation, adsorption, ash, lime, sawdust.

\section{INTRODUCTION}

Pollution of the environment by toxic heavy metals arises as a result of many activities largely industrial, although sources such as agriculture and sewage disposal also contribute. Heavy metal contamination exists in aqueous wastes of metal plating, mining operation, tanneries, radiator manufacturing, smelting, alloy industries and batteries production. Treatment processes for metal removal from liquid wastes include precipitation, ion exchange, adsorption and membrane filtration. Precipitation processes have several disad- vantages, which include incomplete metal removal and sludge generation. In the last decade, alternative means of treating liquid waste containing heavy metals are performed. Biosorption is such a process, on which an increased amount of study is being focused. Natural materials that are available in large quantities, or certain waste products from agricultural operations, may have potential as inexpensive adsorbents. Zeolites, which have the ability to uptake heavy metals, have become known worldwide, because of their cation exchange properties. Sorbents, such as activated carbon, metal oxides 
and ion exchange resins, have also been used. Silica aluminum species, such as silica sand, kaolinite, bauxite, limestone and aluminum oxide could be used to adsorb heavy metals.

Two clear aims can be identified in the present study. The first one includes an overall review of metal retention agents, which have been reported to exhibit satisfactory results when used during the treatment of wastes, accompanied with corresponding function methodologies and mechanisms as well as conditions, under which they yield the desirable results. The second aim of study is the use of by-products like fly ash, agricultural ash, wood dust and lime as retention agents. Such materials have been examined during the treatment of an acidic waste loaded with high concentrations of heavy metals and have exhibited one or more retention mechanisms.

\section{METAL RETENTION AGENTS}

The term 'Metal Retention Agents (MRAs)', which appears in the paper title, includes all the materials, natural or by-products that can retain metals through familiar mechanisms (e.g. adsorption, precipitation, ion exchange etc.). A metal retention agents review has been carried out during the last decade, including study of up-to-date bibliography (1990-2001) and is presented in Table 1.

The table contains a number of general features, which should be examined for every type of material, in case it is expected to be effectively used as a retention agent.

\section{MATERIALS AND METHODS Metal Retention Agents (MRAs)}

Four groups of materials were selected for two reasons. Firstly, their availability in Greece constitutes its use financially favourable. Furthermore, it was expected that these materials would allow a close study of different metal retention mechanisms due to their nature and chemical content.

Lignite Fly Ash (Class C), Agricultural Ashes obtained from Grape Residues, Olive Kernels, Peach Stones and Straw by combustion at $900{ }^{\circ} \mathrm{C}$, as well as Lime and Sawdust were tested for their heavy metals adsorption capacity.

The steps that have been followed before carrying out the treatment are:

- The chemical analysis of the MRAs is presented in Tables 2 and 3.
- Mineralogical (XRD) and SEM analyses were performed in order to determine the main constituents that participate in the metal retention mechanisms.

- A significant factor for the retention effectiveness is the $\mathrm{pH}$ of the reactants. Therefore, measurement of the $\mathrm{pH}$ value was carried out for all MRAs, according to ASTM D-4972 (HANNA Instruments, $\mathrm{pH}$ 301). The values for fly ash, agricultural ashes, lime and sawdust were 13.2, 11-11.5, 11.5 and 5.25 respectively.

- MRAs were examined for their metal content in heavy metals and were leached according to DIN 38414-S4, in order to take into consideration their participation in the waste.

Mineralogical (XRD) and SEM analyses were performed in order to determine the main constituents that participate in the metal retention mechanisms.

A significant factor for the retention effectiveness is the $\mathrm{pH}$ of the reactants. Therefore, measurement of the $p H$ value was carried out for all MRAs, according to ASTM D-4972 (HANNA Instruments, $\mathrm{pH}$ 301). The values for fly ash, agricultural ashes, lime and sawdust were 13.2, 11$11.5,11.5$ and 5.25 respectively.

MRAs were examined for their metal content in heavy metals and were leached according to DIN 38414-S4, in order to take into consideration their participation in the waste.

\section{Waste}

An industrial liquid waste was selected for the study of the MRAs behaviour. It exhibited low $\mathrm{pH}$ values $(\mathrm{pH}=3-4)$ and the metal content is presented in Table 4.

According to the European Directive 4 Volume EEC XII ENV 20/86, the above concentrations are characterised as 'out of specification', in terms of the waste disposal.

\section{Experimental Procedure}

The treatment of the liquid waste with the MRAs took place at ambient temperature. As far as fly ash is concerned, the treatment mixture had a solid/liquid ratio of $60 \mathrm{~g} \mathrm{l}^{-1}$ and was stirred (250 rpm) for $30 \mathrm{~min}$. The corresponding ratio for the agricultural ashes was $5 \mathrm{~g} \mathrm{l}^{-1}$ and the treatment lasted $15 \mathrm{~min}$ at $500 \mathrm{rpm}$. The treatment ratio for sawdust was $40 \mathrm{~g} \mathrm{l}^{-1}$ with a duration of $30 \mathrm{~min}$ at 60 


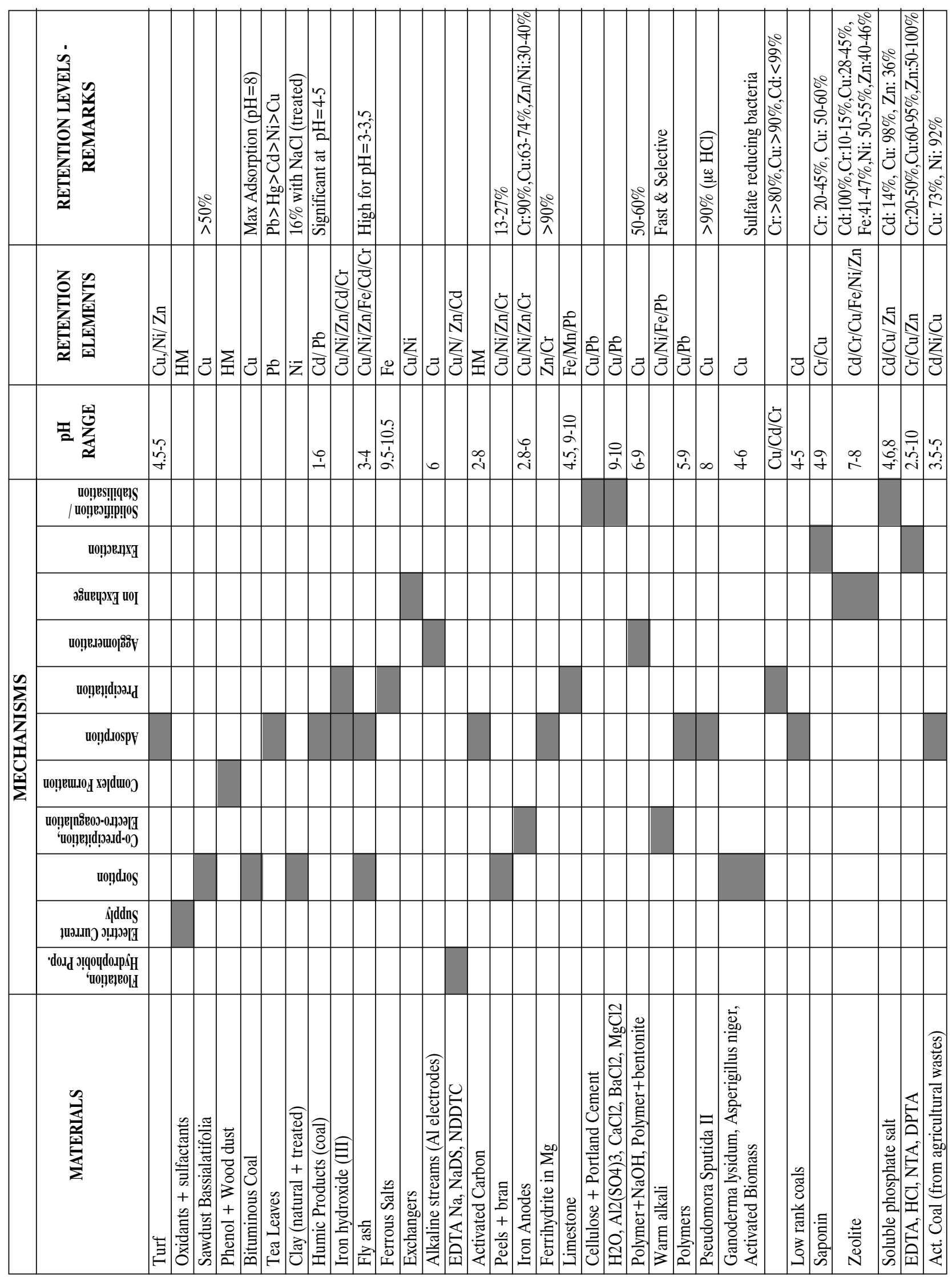


Table 2. Chemical analysis of Fly Ash, Agricultural Ashes and Lime

\begin{tabular}{ccccccc}
\hline $\begin{array}{c}\text { Analysis } \\
\text { Parameters }(\%)\end{array}$ & Lime & Fly Ash & \multicolumn{4}{c}{ Agricultural Ashes } \\
\cline { 4 - 7 } & & & Grape Residue & Olive Kernel & Peach Stone & Straw \\
\hline $\mathrm{Al}_{2} \mathrm{O}_{3}$ & 0.10 & 17.62 & 3.11 & 6.84 & 4.45 & 2.72 \\
$\mathrm{SiO}_{2}$ & 0.22 & 37.84 & 20.80 & 16.95 & 17.05 & 48.59 \\
$\mathrm{~K}_{2} \mathrm{O}$ & 0.08 & 0.25 & 20.25 & 29.60 & 18.24 & 17.81 \\
$\mathrm{Na}_{2} \mathrm{O}$ & 0.10 & 1.10 & 1.82 & 3.31 & 1.43 & 1.68 \\
$\mathrm{CaO}$ & 97.50 & 24.80 & 3.00 & 8.35 & 2.18 & 0.78 \\
$\mathrm{MgO}$ & 1.60 & 4.45 & 2.65 & 2.73 & 3.03 & 1.28 \\
$\mathrm{Fe}_{2} \mathrm{O}$ & 0.04 & 7.58 & 4.52 & 9.70 & 9.59 & 2.84 \\
$\mathrm{L.O.I.}$ & 0.20 & 4.17 & 42.65 & 19.83 & 42.69 & 22.45 \\
\hline
\end{tabular}

Table 3. Chemical analysis of Sawdust

\begin{tabular}{cc}
\hline Analysis Parameters & Concentration $(\mathbf{m g} / \mathbf{l})$ \\
\hline Moisture & 6.87 \\
Ash & 0.40 \\
Volatiles & 76.28 \\
Cellulose & 49.10 \\
Semi-cellulose & 25.90 \\
Lignin & 23.80 \\
Extracts & 0.80 \\
\hline
\end{tabular}

Table 4. Waste Metal Content

\begin{tabular}{lllllll}
\hline Metal & $\mathrm{Cu}$ & $\mathrm{Fe}$ & $\mathrm{Zn}$ & $\mathrm{Ni}$ & $\mathrm{Cd}$ & $\mathrm{Cr}$ \\
\hline $\begin{array}{l}\text { Concentration } \\
\left(\mathbf{m g ~ l}^{-1}\right)\end{array}$ & 50.0 & 50.0 & 10.0 & 10.0 & 0.5 & 0.5 \\
\hline
\end{tabular}

rpm. Finally, the solid/liquid ratio for lime, which was used in slurry form, was gradually adjusted to a $\mathrm{pH}$ value of 11.5 . The treatment took place for $30 \mathrm{~min}$ at $500 \mathrm{rpm}$.

The concentration of metals $(\mathrm{Cu}, \mathrm{Fe}, \mathrm{Zn}, \mathrm{Ni}, \mathrm{Cd}$ and $\mathrm{Cr}$ ) was determined in the filtrate by Atomic Adsorption Spectroscopy (Perkin Elmer 3300).

The solid residues of the waste treatment were subjected to leaching tests, in order to examine their behaviour in relation to metals under leaching conditions.

\section{RESULTS AND DISCUSSION}

The mineralogical (XRD) analysis of fly ash (Figure 1) and of the four types of agricultural ashes (Figure 2) led to some first suggestions concerning the metal retention mechanisms that may be expected to function during the acidic waste treatment.
The presence of minerals, like Anorthite $\left(\mathrm{CaAl}_{2} \mathrm{Si}_{2} \mathrm{O}_{8}\right)$, Ettringite $\left(\mathrm{Ca}_{6} \mathrm{Al}_{2}\left(\mathrm{SO}_{4}\right)_{3}(\mathrm{OH})_{12}\right.$. $26 \mathrm{H}_{2} \mathrm{O}$ ) and $\mathrm{Ca}_{3} \mathrm{Al}_{2} \mathrm{O}_{6}$, in fly and agricultural ashes, combined with the low $\mathrm{pH}$ value of the waste, can be an indication of a potential chemical adsorption of waste metals. In addition, the significant concentration of calcium in both ashes can justify a metal retention through precipitation.

As far as lime and sawdust are concerned, bibliography suggests that they are expected to carry out metal retention through single mechanisms, precipitation and sorption respectively.

\section{Fly Ash - Agricultural Ashes}

After the treatment with fly ash (solid/liquid ratio of $60 \mathrm{~g} \mathrm{l}^{-1}$, stirring at $250 \mathrm{rpm}$ for $30 \mathrm{~min}$ ) measuring of the metals contained in the remaining liquid yielded the following retention percentages (Figure 3). The $\mathrm{pH}$ value of the filtrate was 11 . These results were observed for the optimum solid/liquid ratio after a number of tests. The metal retention percentages were very satisfactory for $\mathrm{Cu}, \mathrm{Zn}$ and $\mathrm{Fe}$. The results were not equally high for the metals that existed in the waste at low concentrations, like $\mathrm{Cr}, \mathrm{Cd}$ and $\mathrm{Ni}$. The relatively low retention percentages of $\mathrm{Ni}$ can be explained by the probable inadequacy of the treatment duration (30 $\mathrm{min})$, as it was proved by additional results. Low retention values of cadmium at high temperature prove its physical adsorption, verified by the results of the leaching tests, while the alkaline environment favours it. The retention of chromium is favoured by acidic environment, which did not prevail in the present experimental process.

The retention of these metals, which depends on the $\mathrm{pH}$ value, occurs mainly through chemical 


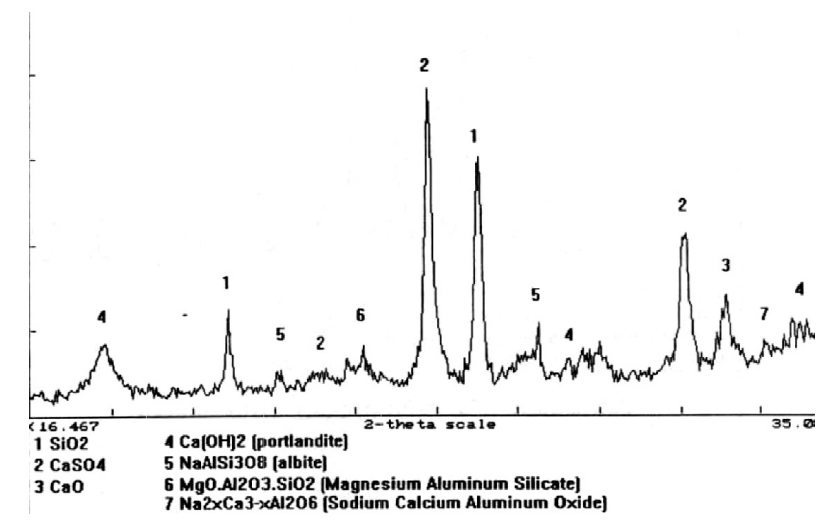

Figure 1. Fly Ash XRD pattern

1: $\mathrm{SiO}_{2}$

2: $\mathrm{CaCO}_{3}$

3: $\mathrm{Ca}_{3} \mathrm{Al}_{2} \mathrm{O}_{6}$

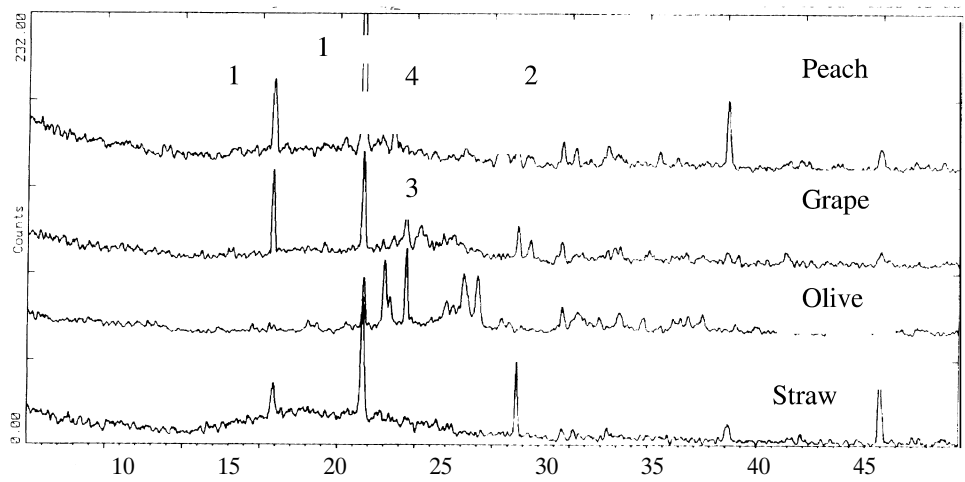

Figure 2. Agricultural Ashes XRD pattern

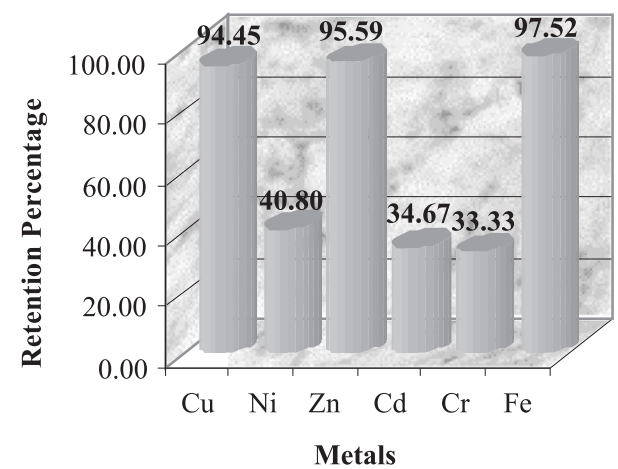

Figure 3. Metal Retention Percentages by Fly Ash

adsorption by $\mathrm{Al}_{2} \mathrm{O}_{3}$ and through precipitation due to the presence of $\mathrm{CaO}$.

The fly ash aluminium oxides $\left(\mathrm{Al}_{2} \mathrm{O}_{3}\right)$, which are close to the water dipoles, redistribute the electrical charges due to the electrochemical properties of the two phases at the solid-solution interface and they form water-oxide interface. The progress of adsorption is governed by the amphoteric dissociation of such aqua complexes of the oxides in the following manner,

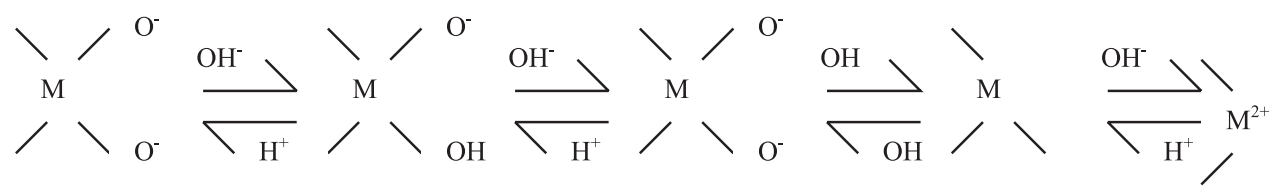




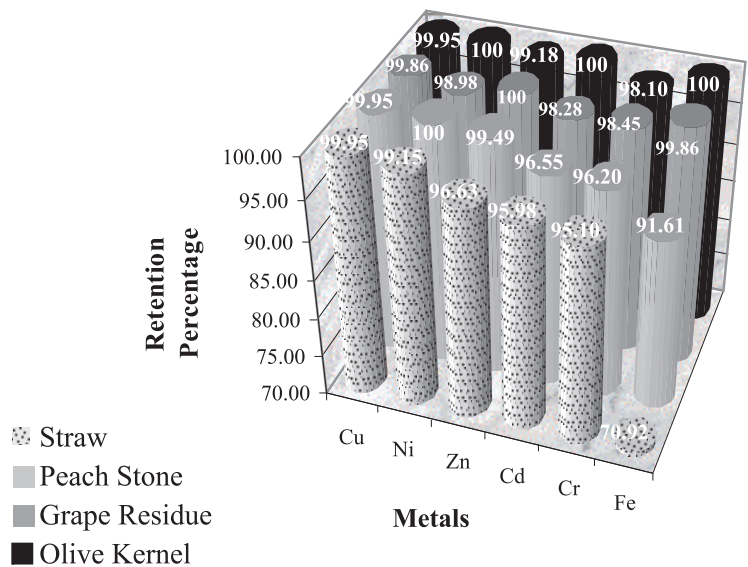

Figure 4. Metal Retention Percentage by Agricultural Ashes

where $\mathrm{M}$ stands for Al. These positively and/or negatively charged surfaces, on the metal oxide of fly ash, seems to be responsible for the adsorption of the metals present in the waste. The retention of metals through a precipitation mechanism occurred due to the fact that fly ash contained $\mathrm{CaO}_{\text {free }}=2.11 \%$ and $\mathrm{CaO}_{\text {available }}=7.35 \%$.

The retention percentages accomplished during the treatment of the liquid waste with samples of agricultural ashes are presented in Figure 4.

The optimum behaviour is exhibited by olive kernels and grape residues, which yield retention percentages that exceed $98 \%$ for all metals. The retention mechanisms, which prevailed in this experimental series, do not differ from the ones identified for fly ash treatment due to the similar nature of the two MRAs.

The aforementioned conclusions were confirmed by the figures of the performed leaching tests (Table 5).

The excellent behaviour of fly ash and agricultural ashes under leaching conditions verifies the metal retention mainly through precipitation and proves that adsorption mechanisms are not reversible, as the solid residue does not seem to discard significant concentrations of metal complexes, with the exception of Cr. Therefore, the produced solid residues can be either disposed in landfills or exploited for acidic soil sanitation due to their increased alkalinity.

\section{Lime - Sawdust}

Sawdust, as a natural product, exhibited a granulometric variety. In order to study the retention process, apart from the initial sample, three gramulometric fractions were produced by sieving $(+500$ $\mu \mathrm{m},-500+200 \mu \mathrm{m},-200 \mu \mathrm{m})$. The optimum results were accomplished by the initial and the $-200 \mu \mathrm{m}$ fraction (Figure 5). The retention percentages accomplished are presented in Figures 5 and 6.

As far as sawdust is concerned, it was observed that for metals that exhibited increased concentrations in the waste, like $\mathrm{Cu}$ and $\mathrm{Fe}$, the retention was relatively higher.

The results of the leaching tests for sawdust are presented in Table 6 .

Table 5. Leaching Test of Fly Ash and Agricultural Ashes

\begin{tabular}{cccccc}
\hline Metals & Fly & \multicolumn{4}{c}{ Agricultural Ashes } \\
\cline { 3 - 6 }$(\mathbf{p p m})$ & Ash & Grape Residue & Olive Kernel & Peach Stone & Straw \\
\hline $\mathrm{Cu}$ & 0.06 & 0.10 & 0.08 & 0.74 & 0.32 \\
$\mathrm{Ni}$ & $<0.01$ & $<0.01$ & $<0.01$ & $<0.01$ & $<0.01$ \\
$\mathrm{Zn}$ & 0.04 & 0.06 & 0.06 & 0.07 & 0.06 \\
$\mathrm{Cd}$ & 0.03 & 0.01 & 0.05 & 0.06 & 0.06 \\
$\mathrm{Cr}$ & 0.05 & 0.02 & 0.03 & 0.03 & 0.03 \\
$\mathrm{Fe}$ & 0.31 & 0.25 & 0.25 & 0.35 & 0.10 \\
\hline
\end{tabular}




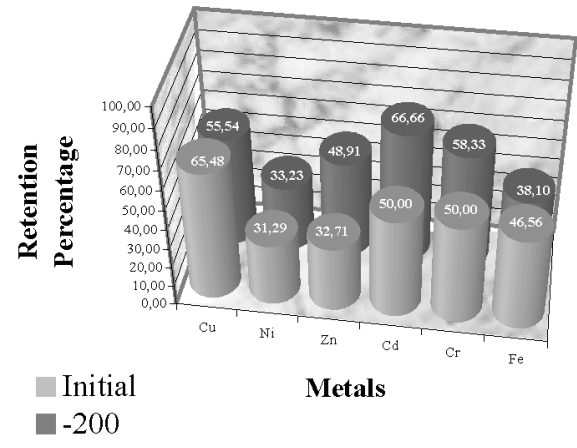

Figure 5. Metal Retention Percentages by Sawdust

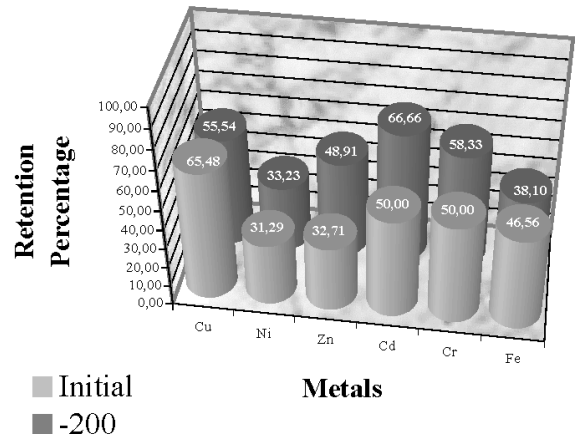

Figure 6. Metal Retention Percentages by Lime

Table 6. Leaching of Sawdust

\begin{tabular}{ccccccc}
\hline $\begin{array}{c}\text { Granulometry } \\
(\boldsymbol{\mu m})\end{array}$ & $\begin{array}{c}\mathbf{C u} \\
(\mathbf{p p m})\end{array}$ & $\begin{array}{c}\mathbf{F e} \\
(\mathbf{p p m})\end{array}$ & $\begin{array}{c}\mathbf{N i} \\
(\mathbf{p p m})\end{array}$ & $\begin{array}{c}\mathbf{Z n} \\
(\mathbf{p p m})\end{array}$ & $\begin{array}{c}\mathbf{C r} \\
(\mathbf{p p m})\end{array}$ & $\begin{array}{c}\mathbf{C d} \\
(\mathbf{p p m})\end{array}$ \\
\hline Initial & 5.92 & 4.20 & 0.15 & 0.45 & 0.02 & 0.01 \\
-200 & 5.30 & 4.43 & 0.11 & 0.36 & 0.01 & $<0.01$ \\
\hline
\end{tabular}

None of the above figures indicates that the metals leached are found in prohibiting concentrations, when compared to the legislatively acceptable ones. On the other hand, these concentrations are significantly high when compared to the ones adsorbed by sawdust. Therefore, the metal retention mechanism that prevailed during the waste treatment seems to be sorption.

The metal retention accomplished by lime was very satisfactory (Figure 6). As expected, it acts through precipitation for all metals. Nevertheless, the participation of sorption, to a small extent, seems possible for some metals, as indicated by the leaching test results (Table 7).

The concentrations of $\mathrm{Cd}$ and $\mathrm{Cr}$ after leaching are slightly increased, compared to the retention percentages and concentrations during the treat-
Table 7. Leaching Test of Lime

\begin{tabular}{lllllll}
\hline Metal & $\mathrm{Cu}$ & $\mathrm{Fe}$ & $\mathrm{Zn}$ & $\mathrm{Ni}$ & $\mathrm{Cd}$ & $\mathrm{Cr}$ \\
\hline $\begin{array}{l}\text { Concentration } \\
\left(\mathbf{m g ~ l}^{\mathbf{1}}\right)\end{array}$ & 0.90 & 0.53 & 0.07 & 0.15 & 0.15 & 0.24 \\
\hline
\end{tabular}

ment. Therefore, it is concluded that a small part of these metals are captured through sorption. Nevertheless, the disposal of the solid residue cannot be legitimately banned. The results of the four MRAs study can be summarised in Table 8 .

\section{CONCLUSIONS}

The experimental study of fly ash, agricultural ashes, sawdust and lime led to the following steps that should be examined, in case a material suit- 
Table 8. Metal Retention Agents Experimental Results

\begin{tabular}{|c|c|c|c|c|c|c|}
\hline \multirow[b]{2}{*}{ MATERIALS } & \multicolumn{3}{|c|}{ MECHANISMS } & \multirow[b]{2}{*}{$\begin{array}{c}\text { pH } \\
\text { RANGE }\end{array}$} & \multirow[b]{2}{*}{$\begin{array}{c}\text { RETENTION } \\
\text { ELEMENTS }\end{array}$} & \multirow[b]{2}{*}{ RETENTION LEVELS } \\
\hline & :气 & $\frac{\Xi}{\frac{0}{0}}$ & & & & \\
\hline Lignite Fly Ash & & & & 11.0 & $\begin{array}{l}\mathrm{Cu} / \mathrm{Ni} / \mathrm{Zn} / \\
\mathrm{Cd} / \mathrm{Cr} / \mathrm{Fe}\end{array}$ & $\begin{array}{l}\mathrm{Cu}: 94.45 \%, \mathrm{Ni}: 40.68 \% \\
\mathrm{Zn}: 95.59 \%, \mathrm{Cd}: 34.67 \% \\
\mathrm{Cr}: 2.40 \%, \mathrm{Fe}: 97.52 \%\end{array}$ \\
\hline Grape Residue Ash & & & & 10.2 & $\begin{array}{l}\mathrm{Cu} / \mathrm{Ni} / \mathrm{Zn} / \\
\mathrm{Cd} / \mathrm{Cr} / \mathrm{Fe}\end{array}$ & $\begin{array}{l}\mathrm{Cu}: 99.86 \%, \mathrm{Ni}: 98.98 \% \\
\mathrm{Zn}: 100 \%, \mathrm{Cd}: 98.28 \% \\
\text { Cr: } \%, \mathrm{Fe}: 99.86 \%\end{array}$ \\
\hline Olive Kernel Ash & & & & 11.7 & $\begin{array}{l}\mathrm{Cu} / \mathrm{Ni} / \mathrm{Zn} / \\
\mathrm{Cd} / \mathrm{Cr} / \mathrm{Fe}\end{array}$ & $\begin{array}{l}\text { Cu: } 99.95 \%, \mathrm{Ni}: 100 \% \\
\text { Zn: } 99.18 \%, \mathrm{Cd}: 100 \% \\
\text { Cr: } 98.10 \%, \mathrm{Fe}: 100 \%\end{array}$ \\
\hline Peach Stone Ash & & & & 7.9 & $\begin{array}{l}\mathrm{Cu} / \mathrm{Ni} / \mathrm{Zn} / \\
\mathrm{Cd} / \mathrm{Cr} / \mathrm{Fe}\end{array}$ & $\begin{array}{l}\mathrm{Cu}: 99.95 \%, \mathrm{Ni}: 100 \% \\
\mathrm{Zn}: 99.49 \%, \mathrm{Cd}: 96.55 \% \\
\mathrm{Cr}: \%, \mathrm{Fe}: 81.61 \%\end{array}$ \\
\hline Straw Ash & & & & 8.9 & $\begin{array}{l}\mathrm{Cu} / \mathrm{Ni} / \mathrm{Zn} / \\
\mathrm{Cd} / \mathrm{Cr} / \mathrm{Fe}\end{array}$ & $\begin{array}{l}\mathrm{Cu}: 99.95 \%, \mathrm{Ni}: 99.15 \% \\
\mathrm{Zn}: 96.63 \%, \mathrm{Cd}: 34.67 \% \\
\text { Cr: } 2.40 \%, \mathrm{Fe}: 97.52 \%\end{array}$ \\
\hline Lime & & & & $11.0-12.0$ & $\begin{array}{l}\mathrm{Cu} / \mathrm{Ni} / \mathrm{Zn} / \\
\mathrm{Cd} / \mathrm{Cr} / \mathrm{Fe}\end{array}$ & $\begin{array}{l}\mathrm{Cu}: 86.53 \%, \mathrm{Ni}: 98.20 \% \\
\mathrm{Zn}: 92.20 \%, \mathrm{Cd}: 82.00 \% \\
\text { Cr: } 77.61 \%, \mathrm{Fe}: 99.19 \%\end{array}$ \\
\hline Sawdust & & & & $4.9-5.3$ & $\begin{array}{l}\mathrm{Cu} / \mathrm{Ni} / \mathrm{Zn} / \\
\mathrm{Cd} / \mathrm{Cr} / \mathrm{Fe}\end{array}$ & $\begin{array}{l}\mathrm{Cu}: 65.48 \%, \mathrm{Ni}: 31.29 \% \\
\mathrm{Zn}: 32.71 \%, \mathrm{Cd}: 50.00 \% \\
\mathrm{Cr}: 50.00 \%, \mathrm{Fe}: 46.56 \%\end{array}$ \\
\hline
\end{tabular}

ability is tested, in relation to its effectiveness as MRA:

- Chemical and Mineralogical Data: Methodologies like XRD, SEM, DSC are quite useful, as far as the determination of the mineralogical characteristics of the materials is concerned (e.g. $\mathrm{SiO}_{2}, \mathrm{Ca}(\mathrm{OH})_{2}, \mathrm{CaO}, \mathrm{Al}_{2} \mathrm{O}_{3}$ ). The analyses that were conducted in the present study verified the presence of aluminum, silica and calcium phases in the four MRAs.

- Process $p H$ : The value that results from the combination of the solid (MRA) and liquid (waste) $\mathrm{pH}$ values. When accompanied with the above methodologies, it allows the determination of the prevailing retention mechanisms. Specifically, it was concluded that in alkaline environment aluminum and calcium were the material constituents that participat- ed in the metal retention through chemical adsorption and precipitation respectively, while acidic conditions favoured silica participation and subsequently sorption as metal retention mechanism.

- Leaching Test: Confirmation of the retention mechanisms previously indicated is feasible through evaluation of the concentrations of the metals leached.

Table 8, which corresponds to the general Table 1 , was the outcome of the data gathered from these steps. It should be taken into account that these tables themselves should not be used as MRA index for waste treatment applications. Carrying out of the aforementioned steps can only lead to characterisation of a material as MRA and thus construction of such tables.

The study of the four MRAs, which was the sec- 
ond aim of the present paper, proved the effectiveness of fly ash, agricultural ashes and lime and of sawdust to a lesser extent, in terms of metal retention from an acidic liquid waste.

\section{REFERENCES}

Ayala J., Blanco F., Garcia P. (1998), Austrian fly ash as a heavy metals removal material, Fuel, 77, 1147-1154.

Kannan N. (1991), A study on removal of nickel by adsorption on fly ash, Indian Journal of Environmental Protection, 11, 514-518.

Korkolis A., Chalarakis E, Crysakopoulos A., Moutsatsou A. (2000), Study of the behaviour of agricultural ashes concerning the combustion process of the raw material, R'2000 Recovery Recycling Re-integration Proceedings, Toronto, Canada, 577-583.

Ping-Chin Hsiau, Shang-Lien Lo (1997), Effects of lime treatment on fractionation and extractabilities of heavy metals in sewage sludge, Journal of Environmental Science and Health, Part A, 32, 2521-2536.

Raji C., Shubha K., Anirudhan T. (1997), Use of chemically modified sawdust in the removal of $\mathrm{Pb}$ (II) from aqueous media, Indian Journal Environmental Health, 39, 230-238.

Viraraghavan T., Rao Ganesh A. (1990), Removal of cadmium and chromium from wastewater using fly ash, Proc. Ind. Waste Conf., 45, 517-527.

Xirokostas N., Moutsatsou A, Arvelakis S., Koukios E. (2000), Study of the behaviour of fly ash during the retention of metals from alcoholic beverage distillation residues, R'2000, Recovery Recycling Re-integration Proceedings, Toronto, Canada, 1076-1081.

Zarraa Mahmoud A. (1995), A study on the removal of chromium (VI) from waste solutions by adsorption on to sawdust in stirred vessels, Adsorption Science and Technology, 12, 129-138. 
